\title{
Masticatory Changes in Oral Breath Secondary to Allergic Rhinitis: Integrative Review
}

\author{
Luciana Ângelo Bezerra ${ }^{1}$ Hilton Justino da Silva ${ }^{2}$ Ana Carolina Cardoso de Melo ${ }^{3}$ \\ Klyvia Juliana Rocha de Moraes ${ }^{4}$ Renata Andrade da Cunha ${ }^{1}$ Daniele Andrade da Cunha ${ }^{2}$ \\ Décio Medeiros ${ }^{5}$ \\ ${ }^{1} \mathrm{MSc}$ in Health Science/Universidade Federal de Pernambuco-UFPE, \\ Address for correspondence Luciana Ângelo Bezerra, UFPE \\ Recife, PE, Brazi \\ $2 \mathrm{PhD}$ in Nutrition/UFPE. Department of Human Comunication Health/ \\ UFPE, Recife, PE, Brazil \\ ${ }^{3} \mathrm{MSc}$ in Human Comunication Health/UFPE, Recife, PE, Brazil \\ ${ }^{4} \mathrm{MSC}$ in Pathology/UFPE, Recife, PE, Brazil \\ ${ }^{5} \mathrm{PhD}$ in Pediatrics/UNIFESP. Department of Pediatrics of UFPE, Recife, \\ PE, Brazil

\begin{abstract}
Keywords

- mastication

- rhinitis

- allergic

- seasonal

- mouth breathing

Introduction The III Brazilian Consensus on Rhinitis (2012) defines allergic rhinitis as a nasal mucosa inflammation, mediated by immunoglobulin $E$, after exposure to allergens. The classic signs and symptoms of allergic rhinitis are nasal obstruction, watery rhinorrhea, sneezing, and nasal itching, often reversible either spontaneously or with treatment, and mouth breathing (breathing predominantly through the mouth, regardless of the cause, due to a nasal breathing impairment) in some cases.

Objective To evaluate the literature on masticatory changes in children with mouth breathing due to allergic rhinitis.

Methods We conducted a search of the past 10 years, at Bireme and MEDLINE databases, for articles that covered masticatory changes in children with mouth breathing secondary to allergic rhinitis.

Results We found 1,986 articles, including 15 repeated in databases, but only two articles met the inclusion criteria fully.

Discussion We found few studies to answer the question raised in this review, and those studies have some methodological limitations. Most articles claimed no have statistically significant differences in masticatory changes in this population.

Conclusion A better controlled study (isolating diseases, exposure time), with a larger sample (sample calculation appropriate), would be necessary to examine such changes.
\end{abstract}

\section{Introduction}

The III Brazilian Consensus on Rhinitis (2012) defines allergic rhinitis as an nasal mucosa inflammation, mediated by immunoglobulin E, after exposure to allergens. ${ }^{1}$ According to ARIA (Allergic Rhinitis and Its Impact on Asthma) initiative recommendation, allergic rhinitis can be classified received

June 15, 2013

accepted

July 7, 2013
DOI http://dx.doi.org/

10.1055/s-0033-1358585. ISSN 1809-9777.
Copyright $(\underset{0}{ } 2014$ by Thieme Publicações License terms Ltda, Rio de Janeiro, Brazil
(®) (1) $\Theta \circledast$ 
Table 1 Intersections in Portuguese, English, and Spanish idioms

\begin{tabular}{|l|l|l|}
\hline Mastication AND Mouth Breathing & Mastigação AND Rinite Alérgica & Masticatión AND Respiración por la boca \\
\hline Mastication AND Allergic Rhinitis & $\begin{array}{l}\text { Rinite Alérgica AND Respiração } \\
\text { Oral OR Respirador Bucal OR Respirador } \\
\text { OR Respiração Bucal }\end{array}$ & $\begin{array}{l}\text { Mastigação AND Respiração Oral OR } \\
\text { Respirador Bucal OR Respirador OR } \\
\text { Respiração Bucal }\end{array}$ \\
\hline Mouth Breathing AND Allergic Rhinitis & La Rinitis Alérgica AND Masticatión & $\begin{array}{l}\text { La Rinitis Alérgica AND Respiración } \\
\text { por la boca }\end{array}$ \\
\hline & Masticatión AND Boca des Respiradero & $\begin{array}{l}\text { La RinitisAlérgica AND Boca des } \\
\text { Respiradero }\end{array}$ \\
\hline
\end{tabular}

considering the duration (intermittent, persistent) and severity (mild, moderate, and severe) of the symptoms, quality of life aspects, and frequency that the allergic rhinitis arises (seasonal, perennial, circumstantial, and occupational). ${ }^{1}$ The classic signs and symptoms of allergic rhinitis are nasal obstruction, watery rhinorrhea, sneezing, and nasal itching, often reversible either spontaneously or with treatment, and mouth breathing (breathing predominantly through the mouth, regardless of the cause, due to a nasal breathing impairment) in some cases. ${ }^{1-4}$ This causes myofunctional imbalances and changes in stomatognathic functions and at the body axis. ${ }^{5}$ Several physical characteristics are observed in this population because of oral respiratory habits, such as craniofacial changes (vertical rise of the lower third of the face, dental malocclusion, jaw elevator muscles hypotonia, changes in tongue rest posture) and oral functions changes (swallowing, speech, voice, chewing). ${ }^{1-7}$

In individuals with allergic rhinitis, mouth breathing commonly causes evident changes in chewing, which can lead to muscle compensation suggesting a masticatory preference side, creating a muscle misalignment. So, knowledge about masticatory changes is necessary to better prevent more serious maladjustment.

This integrative literature review was developed with the objective to verify the masticatory changes in children with mouth breathing due to allergic rhinitis by gathering scientific subsidies available in the literature.

\section{Methods}

Initially the research question formulated was: What are the masticatory changes in children with mouth breathing secondary to allergic rhinitis? A search was conducted of publications in the past 10 years in Bireme (search engines LILACS, MEDLINE, SciELOBr) and MEDLINE (PubMed search engine) databases for articles that covered masticatory changes in children with mouth breathing secondary to allergic rhinitis.

We used the following keywords: Mastication and Mouth Breathing as DeCS/MeSH terms, Allergic Rhinitis as free term/ $\mathrm{MeSH}$, and Mouth Breathing and Oral Breathing as free terms, in Portuguese, English, and Spanish idioms. The crosses with these words were made using the Boolean operator $A N D$, without limitation language, and are shown in - Table 1.
The inclusion criterion for this review was an approach to the masticatory in allergic rhinitis. First, original scientific articles were included that approached masticatory changes in children and adolescents with mouth breathing secondary to allergic rhinitis in its title. Then, these articles were analyzed by reading their abstracts, conducted by the three examiners; only those articles that approached masticatory changes in children and adolescents with mouth breathing secondary to allergic rhinitis were later included in the review. We excluded articles that did not approach masticatory changes in this population, review articles, and a single case study.

The articles were read in their entirety, excluding those that did not fit the inclusion criteria. No article was deleted due to idioms.

\section{Results}

-Fig. 1 shows the flowchart of the articles number in this review by intersections as described in - Table 1 .

The end result of this review is found in - Table $\mathbf{2}$.

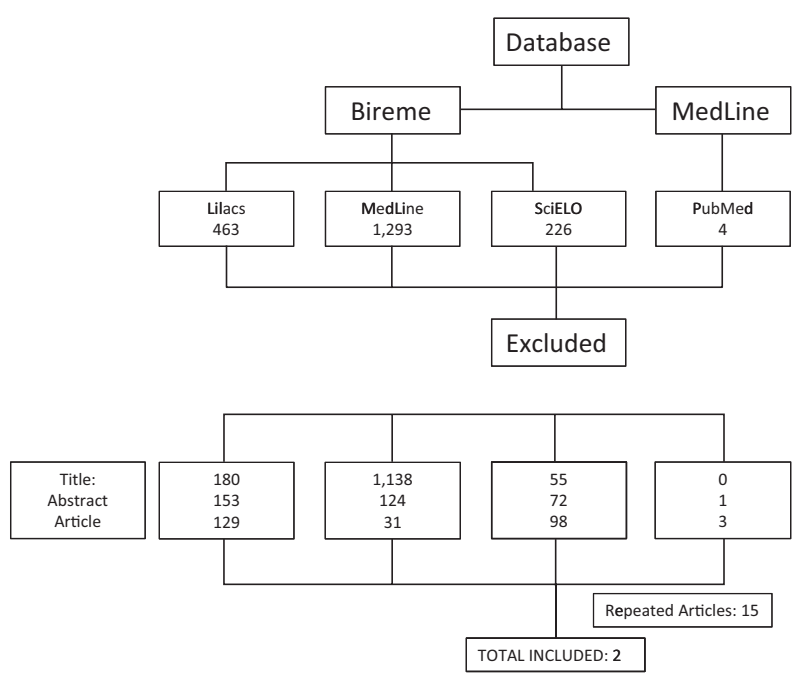

Fig. 1 Flowchart representing the number of articles found, deleted, and selected for this review. 
130 Masticatory Changes Secondary to Allergic Rhinitis Bezerra et al.

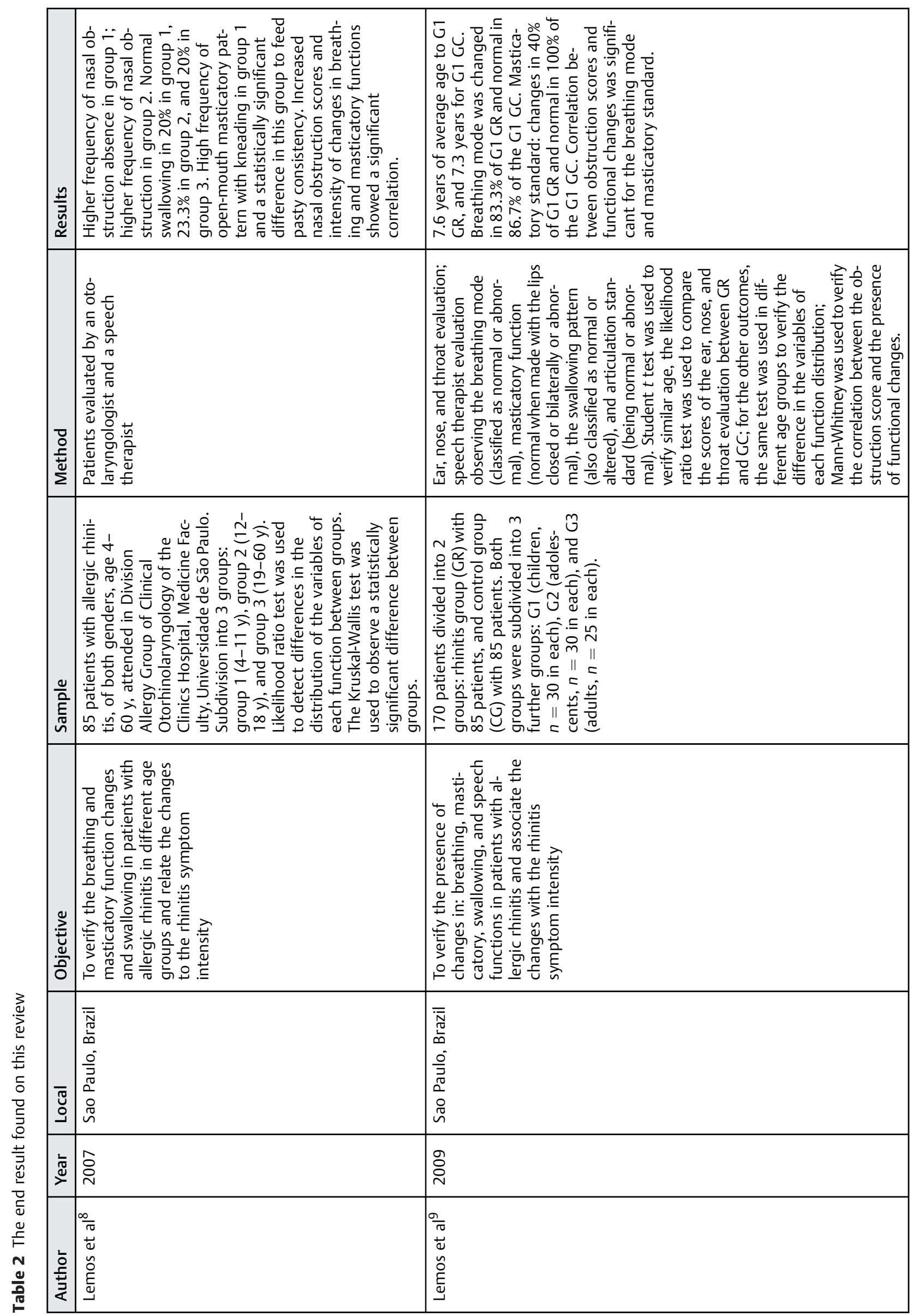

International Archives of Otorhinolaryngology Vol. 18 No. 2/2014 


\section{Discussion}

We found few published studies addressing the question raised in this review, and those studies had methodological limitations. The two selected articles have the same authors and demonstrated a difference in masticatory function ${ }^{8,9}$ in this population with allergic rhinitis when study subjects were compared with healthy subjects and/or to the literature.

Both articles suggested changes in relation to labial closure during chewing function, but one article reports only chewing with open mouth and the preference for soft foods, ${ }^{8}$ and the other article does not define whether the changes found in chewing refer only to absence of labial closure and/or without bilateral mastication. ${ }^{9}$

Although knowledge of the likely craniofacial changes resulting from mouth breathing are already well defined, and it is known that these changes bring masticatory changes, ${ }^{10-12}$ we know the changes are not just due to the act of chewing with the mouth open and/or bilateral mastication.

Other studies with masticatory changes due to mouth breathing showed that this habit constantly keeps the mouth open, preventing the tongue from pressing the palate; then the hard palate tends to rise and begins to present distoclusion and cross-bites. ${ }^{13}$ All this further stimulates the individual to breathe through the mouth.

Lima et al, in their 2006 study with 26 children $\sim 5$ to 7 years old, evaluated chewing by filming mastication of a 50 -g piece of French bread. ${ }^{14}$ They concluded that the mastication of most of the children (76.9\%) occurred with labial closure and did not present kneading chewing. Regarding the chewing pattern, the majority of the children showed a bilateral alternated mastication pattern (10 children), bilateral with only vertical movements and right unilateral (with 6 children in each), and unilateral predominance of the left side (4 children). ${ }^{14}$

Silva et al investigated the likely changes caused by mouth breathing in masticatory function by studying 46 children ( 23 nasal breathing and 23 mouth breathing). ${ }^{15}$ Mastication was evaluated through filming, but the kind of food used was not described; they used the same food for the entire sample. The authors found that mouth-breathing children presented vertical movements associated with rotational jaw movements, and no vertical movements were seen in the nasal-breathing group. Regarding the mastication time, the authors observed a statistically significant difference when comparing the average time between the groups, concluding that the mastication time in the mouth-breathing group was lower than in the nasal-breathing group. ${ }^{15}$

The two Limos et al (2007 and 2009) articles claimed that nasal obstruction was directly related to masticatory changes in function and breathing mode and that probably the time of exposure of the nasal obstruction by the allergic rhinitis negatively interfered with child development. ${ }^{8,9}$

\section{Conclusion}

We could not find in this integrative review studies that assessed chewing performance in depth in children with mouth breathing secondary to allergic rhinitis. The few articles found did not stop these changes.

According to the articles evaluated and discussed, it can be concluded that there are statistically significant changes in mastication in a child with mouth breathing secondary to allergic rhinitis when compared with children without allergic rhinitis with nasal breathing. However, it is necessary to conduct a better-controlled study (isolating diseases and exposure time) with a larger sample (appropriate sample calculation) to assert such changes.

So far, none of the articles surveyed and/or evaluated in this review approached the masticatory preference side, including mastication time or other likely changes of masticatory function in this population.

\section{References}

1 Solé D, Sakano E, Dolci JEF et al. III Consenso Brasileiro sobre Rinites 2012. Braz J Otorhinolaringol 2012;75(6):9-32

2 Di Francesco RC, Passerotir G, Paulucci B, Miniti A. Respiração oral na criança: repercussões diferentes de acordo com o diagnóstico. Rev Bras Otorrinolaringol 2004;70(5):665-670

3 Abreu RR, Rocha RL, Lamounier JA, Guerra AFM. Etiologia, manifestações clínicas e alterações presentes nas crianças respiradoras orais. J Pediatr 2008;84(6):529-535

4 Motta LJ, Martins MD, Fernandes KPS, Mesquita-Ferrari RA, Biasotto-Gonzalez DA, Bussadori SK. Relação da postura cervical e oclusão dentária em crianças respiradoras orais. Rev CEFAC 2009; 11(3):274

5 Winnberg A, Pancherz H. Head posture and masticatory muscle function. An EMG investigation. Eur J Orthod 1983;5(3):209-217

6 Postiaux G. Fisioterapia respiratória pediátrica: o tratamento guiado por ausculta oulmonar. 2ª ed. São Paulo: Artmed; 2004

7 Tavares CA, Braga IP, Silva HJda. Alterações posturais no respiradores orais. J Bras Fonoaudiol 2002;3(12):233-236

8 Lemos CMde, Wilhelmsen NSW, Mion O, Mello Júnior JFde. Alterações funcionais do sistema estomatognático em pacientes com rinite alérgica. Int Arch Otorhinolaringol 2007;11(4):380-386

9 Lemos CMde, Wilhelmsen NSW, Mion O, Mello Júnior JFde. Alterações funcionais do sistema estomatognático em pacientes com rinite alérgica: estudo caso-controle. Braz J Otorhin 2009;75(2): 268-274

10 Di Francesco RC, Passerotii G, Paulucci B, Miniti A. Respiração oral na criança: repercussões diferentes de acordo com o diagnóstico. Rev Bras Otorrin 2004;70(5):665-670

11 Imbaud T, Wandalsen G, Nascimento Filho E, Wandalsen NF, Mallozi Mde C, Sole D. Respiração bucal em pacientes com rinite alérgica: fatores associados e complicações. Rev Bras Alergia Imunopatol 2006;29(4):183-187

12 Menezes VAde, Tavares RLdeO, Granville-Garcia AF. Síndrome da respiração oral: alterações clínicas e comportamentais. Arq em Odonto 2009;45(3):160-165

13 Cintra CFSC, Castro FFM, Cintra PPVC. As alterações oro-faciais apresentadas em pacientes respiradores bucais. Rev Bras Aler Imunol 2000;23(2):78-83

14 Lima MRF, Freire OCB, Nepomuceno Filho JL, Stampford S, Cunha DA, Silva HJda. Padrão mastigatório em crinaças de 5 a 7 anos: suas relações com crescimento craniofacial e hábitos alimentares. Rev CEFAC 2006;8(2):205-215

15 Silva MAdeAe, Natalini V, Ramires RR, Ferreira LP. Análise comparativa da mastigação de crianças respiradoras nasais e orais com dentição decídua. Rev CEFAC 2007;9(2):190-198 